\title{
Application of the Open Data Kit for Data Collection Presence of Primary School Teachers
}

\author{
Ayi Purbasari ${ }^{1}$, Wanda Gusdya ${ }^{2}$, Ferry Mulyanto ${ }^{3}$, Vina Fitria Nurlatifah ${ }^{4}$ \\ Jurusan Teknik Informatika Universitas Pasundan \\ e-mail: pbasari@unpas.ac.id ,wanda.gusdya@unpas.ac.id , ferry@unpas.ac.id , \\ Vina.153040052@mail.unpas.ac.id
}

To cite this document:

Purbasari, A., Gusdya, W., Mulyanto, F., \& Nurlatifah, V. F. (2020). Application of the Open Data Kit for Data Collection Presence of Primary School Teachers. IAIC Transactions on Sustainable Digital Innovation (ITSDI), 2(2), 158-168.

DOI : https://doi.org/10.34306/itsdi.v2i2.409

\begin{abstract}
The Open Data Kit (ODK) originated as a google.org initiative where research efforts were focused on applying technology to assist developing countries in the health and environment sectors. ODK is an open-source tool that helps organizations, writers / researchers, field workers, and manage mobile data collection solutions. Its goal is to create open-source and standards-based tools that are easy to try, easy to use, easy to modify and easy to measure.

This research was conducted to help teachers and Korwil Operators to collect and manage teacher attendance data at each elementary school in Ciater sub-district by utilizing the Open Data Kit as a medium for collecting and managing primary school teacher attendance data. This research was conducted by conducting literature studies, interviews and observations, and studying the use of the Open Data Kit. Furthermore, the stages will be carried out to define the needs of analysis, design and implementation.

The final result of this research is a presence data collection application that utilizes the Open Data Kit as a medium consisting of ODK Collect as a data collection tool and ODK Aggregate as a tool for managing data.
\end{abstract}

Keywords: Presence, Data Collection, Open Data Kit, ODK Collect, ODK Aggregate, Korwil Pendidikan, Elementary Schools, Teachers

\section{Introduction}


Education is a learning process, fostering and directing so that students are willing and able to learn, understand and understand education. Educational development is an effort to educate the nation's life and improve human resources (HR). By mastering science and technology so that he becomes a human being who is faithful, devoted to God Almighty, virtuous, intelligent, skilled, physically and mentally healthy. The administration of education is not a ceremonial life, but the implementation of education is an initial development in the selection of students so that it has meaning, meaning for their lives. The Ciater Subdistrict Education Korwil Institute is an organizational structuring environment in the context of managing education clearly by paying attention to the effectiveness and efficiency as well as the equity of education and the existence of education relevance to the needs of the community. The need for educational personnel as well as educational facilities and infrastructure is very dominant, for the smooth running of the education process at various levels and types of education. The implementation of teacher presence in every elementary school still uses the signature method on a sheet of paper that has been formatted every day, and the collection of teacher attendance data in every elementary school in the district is still done by each teacher collecting teacher attendance data every month to the UPTD office or the Regional Coordinator With irregular collection times, it makes it difficult for teachers when office operators ask for attendance data suddenly. With this problem the UPTD Office or the Regional Coordinator needed

a system that makes it easier for operators to perform teacher presence in every elementary school in Ciater District.

Currently, mobile systems have been widely implemented in various fields, one of which is the Open Data Kit (ODK). ODK was introduced as a tool in building information services for developing regions [1]. ODK itself continues to experience developments in ODK Tables, namely organizing data into smartphone database tables. [2] [3]. Therefore, the writer raises this issue as the topic of a final project entitled "Open Data Kit for Primary School Teacher Presence Data Collection at the Korwil Pendidikan, Ciater District, Subang Regency".

\section{Basic Theory}

Data Collection Based on Android Smartphones Using the Open Data Kit System. In this study the problem raised was the ineffective data collection, although there are a lot of data collection systems using cell phones, but very few use the latest features such as GPS, photos and International Mobile Equipment Identity. (IMEI). All of these features are used to improve data quality, for example, GPS can provide information on whether the data collector or interviewer is coming at the right place or not, photos for verification of the object visited and IMEI to ensure that data transmission from devices that have been registered so as to avoid errors data source. For this reason, 2.9.1 research proposes the use of the Open Data Kit as a solution for data collection [4]

Implementation of the Open Data Kit (ODK) to Improve the Effectiveness of Teacher and School Arrangements. Previously, PPG required operators to collect data by distributing questionnaires, causing errors in data entry by operators and requiring a relatively long time. This study aims to create a prototype PPG application based on ODK by reducing errors in data entry, because it is entered directly by the user. Testing is done by capturing sending data or files from a smartphone and receiving data or files on the server. And to prevent the accumulation of teachers in certain schools, a new system is needed in managing teachers and schools in implementing the joint regulation of the five ministers on Teacher Management and Equity (PPG). The ODK-based PPG application is an effort to build Mobile Data Collection Systems (MDCS) which is currently developing. From these problems, a prototype PPG 
application based on ODK under the Android operating system was designed to record teachers and schools by bringing up real time visualization [5]

Application of Electronic Recapitulation of Teacher \& Employee Attendance (AREA-GP) in Senior High School. Currently the school administration system that is currently running is still being carried out manually where all administrative processes are still using a written form and then processed back into the ledger administration. Of course this work is not safe in recording administrative data carried out by administrative employees, and employees are still difficult to find data about the administration of teachers and employees when it is needed and data loss often occurs when recording administrative bookkeeping, so it can be said that it is still ineffective. Therefore, this attendance data collection does not yet have a good teacher and employee information system. So that leaders or principals have difficulty seeing and assessing the performance of teachers and employees [6]

\section{System Overview}

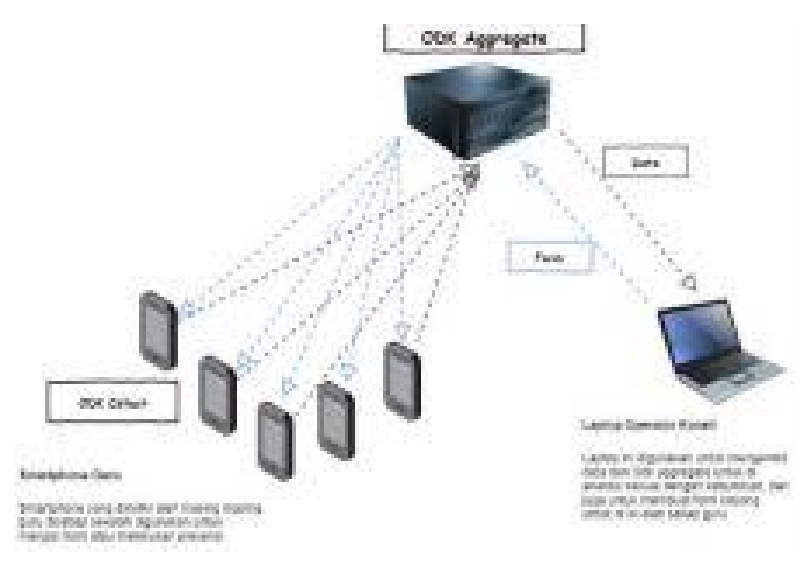

Figure 1 Overview of the Attendance Application System

This research is focused on the Administration of Facilities and Infrastructure of the Korwil of Ciater District. In this section, one of its duties and functions is managing the attendance data of elementary school teachers. The method of collecting attendance data is still less effective, so the authors propose a attendance collection system that uses the Open Data Kit to implement attendance data collection applications. The application to be built is an Android and Web based application.

A. User Requirements

In the process of software requirements analysis, the author has identified the needs of software users The following is a list of user requirements for device users soft. 


\begin{tabular}{|l|l|l|}
\hline No & \multicolumn{1}{|c|}{ User Requirement } & \multicolumn{1}{|c|}{ Description } \\
\hline 1 & $\begin{array}{l}\text { Teachers need system that } \\
\text { can make it easier do } \\
\text { attendance and collection } \\
\text { School Attendance Data }\end{array}$ & $\begin{array}{l}\text { Users need a system application to collect } \\
\text { Teacher attendance data at school }\end{array}$ \\
\hline 2 & $\begin{array}{l}\text { Korwil requires system that } \\
\text { can speed up data collection } \\
\text { presence of Every school }\end{array}$ & $\begin{array}{l}\text { Users need a system application to } \\
\text { manage data presence of teachers in every } \\
\text { school }\end{array}$ \\
\hline
\end{tabular}

B. Use Case Diagram

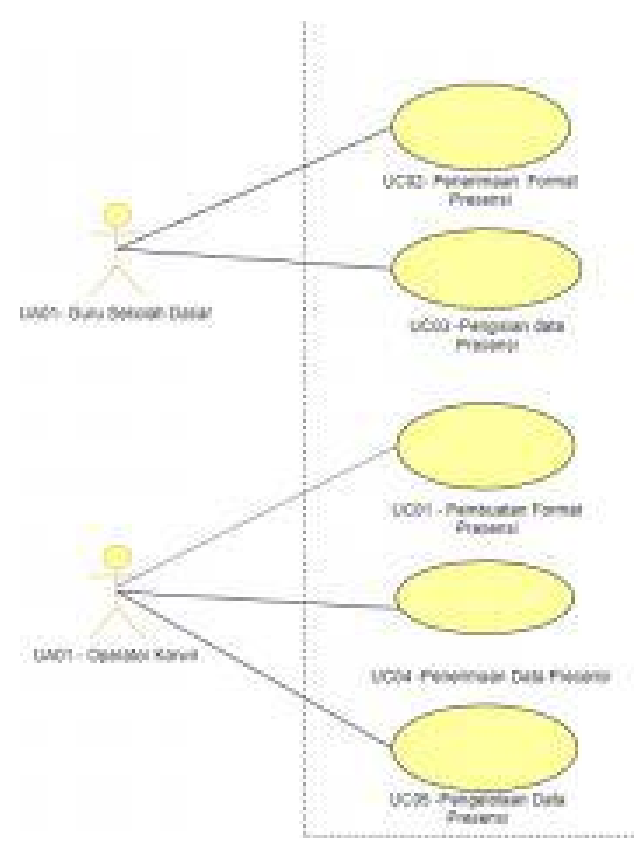

Figure 2 Use Case Diagram

This software for attendance data collection has 5 functionality which is divided into 2 parts, 3 functionalities applied to the website, namely sending attendance format, managing attendance data, and storing attendance data. Then 2 other functionalities that are applied to the mobile application, namely filling in teacher data, sending attendance and receiving data, and displaying attendance data. There are 2 teacher actors and Korwil Operators. 


\section{Implementation}

A. Mobile Application Hardware Specifications (ODK Collect)

The hardware specifications are used when implementing ODK Collect which is part of the teacher attendance data collection application.

Table 2 ODK Collect Hardware Requirements

\begin{tabular}{|l|l|l|}
\hline No & $\begin{array}{l}\text { Device Requirements } \\
\text { Hard }\end{array}$ & Specification \\
\hline 1 & Network & 3 G/4G LTE \\
\hline 2 & CPU & Quad-core Max $1.40 \mathrm{GHz}$ \\
\hline 3 & Memory & 2 GB RAM \\
\hline 4 & GPS & - \\
\hline
\end{tabular}

B. Web Application Hardware Specifications (ODK Aggregate)

As for the hardware specifications used for data management applications that will implement ODK Aggregate which is part of the teacher attendance data collection application.

Table 3 ODK Aggregate Hardware Requirements

\begin{tabular}{|l|l|l|}
\hline No & Device Requirements Hard & Specification \\
\hline 1 & Processor & AMD E1-1200 APU \\
\hline 2 & RAM (Random Access Memory) & 8GB DDR3L \\
\hline 3 & Harddisk & HDD 500GB \\
\hline 4 & Operating System & Windows 10 Pro 64 bit \\
\hline 5 & GPU (Graphics Processing Unit) & $\begin{array}{l}\text { RadeonTM HD Graphics } \\
1.40 \mathrm{GHz}\end{array}$ \\
\hline
\end{tabular}


C. Software Requirements

This section describes the requirements for supporting software that is used when the software will be implemented

Table 4 Software Requirements

\begin{tabular}{|l|l|l|}
\hline No & Device Soft & Source Download \\
\hline 1 & Sublime Text & $\underline{\text { https://www.sublimetext.com }}$ \\
\hline 2 & Draw.ion & $\underline{\text { https://about.draw.io }}$ \\
\hline 3 & ODK Collect & $\underline{\text { https://play.google.com }}$ \\
\hline 4 & ODK Aggregate & $\underline{\text { https://opendatakit.org/software/ }}$ \\
\hline 5 & Mockingbot & $\underline{\text { https://mockingbot.com/ }}$ \\
\hline 6 & App Engine & cloud.google.com/AppEngine \\
\hline
\end{tabular}

D. Main Components of the Open Data Kit System

This section describes the components - Open Data Kit components used for implementing attendance data collection applications. The image will describe the main components of the Open Data Kit.

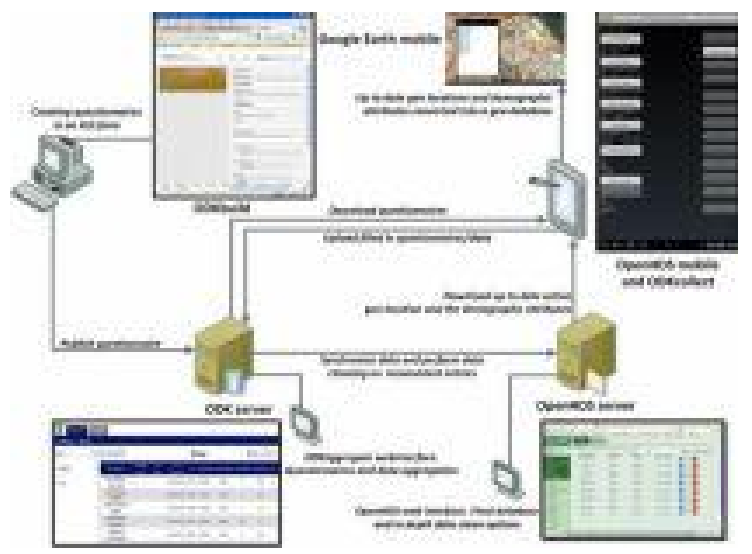

Figure 3 Main Components of the ODK System

E. Stages of Building an Open Data Kit System

There are several stages to building a presence gathering system that is applied to the Open Data Kit, the following are the stages that are intended: 


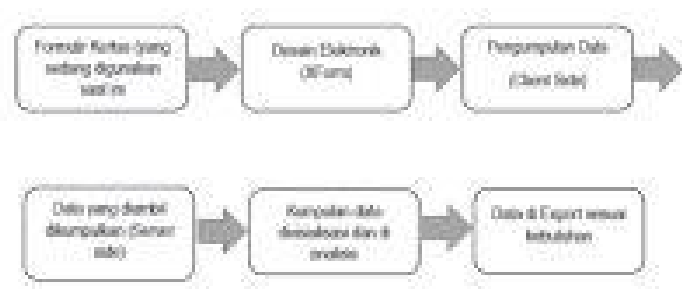

Figure 4 Stages of Building a System

- Paper forms are the medium used today to do attendance in elementary schools in the ward Korwil of Ciater District.

- Electronic Design (Xform) is an XML form that is created to build and adapt to data needed

- Data collection (Client Side) is a collection tool The data used to perform presence is ODK

- Collect Server Side is a web based application for collecting and storing data that has been retrieved on ODK Collect. Server side in question is ODK Aggregate

- Data visualized and analyzed are data collected analyzed as needed and can be visualized to be a pie chart.

- Data is exported, data that has been adjusted can be exported and downloaded as a CSV file.

\section{Server Configuration}

A. Web Server

ODK Aggregate can be installed on several web servers. web server that can be used.

Table 5 Web server

\begin{tabular}{|l|l|l|}
\hline No & Web name Server & Description \\
\hline 1 & Google App Engine & $\begin{array}{l}\text { App Engine is a platform } \\
\text { allows developers to create } \\
\text { and run applications- web } \\
\text { application with hosting } \\
\text { facilities on Google servers }\end{array}$ \\
\hline 2 & Tomcat & $\begin{array}{l}\text { Apache Tomcat is a web } \\
\text { open source servers and } \\
\text { servlets } \\
\text { container developed by } \\
\text { Apache Software Foundation } \\
\text { (ASF). } \\
\text { Tomcat } \\
\text { implementing Java Servlet } \\
\text { and JavaServer Pages (JSP) } \\
\text { from }\end{array}$ \\
\hline
\end{tabular}




\begin{tabular}{|c|c|c|}
\hline & & $\begin{array}{l}\text { Oracle and provide the } \\
\text { environment } \\
\text { "pure Java" HTTP web } \\
\text { server for } \\
\text { running Java code. Apache } \\
\text { Tomcat includes tools for } \\
\text { configuration and } \\
\text { management, but } \\
\text { can also be configured with } \\
\text { edit the XML configuration } \\
\text { file. }\end{array}$ \\
\hline 3 & DigitalOcean & $\begin{array}{l}\text { Digital Ocean is a big name } \\
\text { in the server world, they are } \\
\text { provide infrastructure } \\
\text { cloud-based and all } \\
\text { use SSD then } \\
\text { read write speed is much } \\
\text { more } \\
\text { fast compared to } \\
\text { hard drive }\end{array}$ \\
\hline 4 & Amazon Web Service & $\begin{array}{l}\text { Amazon Web Service (AWS) } \\
\text { is the most cloud platform } \\
\text { comprehensive and widely } \\
\text { used } \\
\text { wide in the world. Offer more } \\
\text { of } 165 \text { complete excellent } \\
\text { services } \\
\text { from data centers globally. }\end{array}$ \\
\hline 5 & Microsoft Azure & $\begin{array}{l}\text { Microsoft Azure is a suite } \\
\text { the Cloud Computing service } \\
\text { keep growing to help } \\
\text { organizations face } \\
\text { challenges } \\
\text { business. In our Microsoft } \\
\text { Azure } \\
\text { in freedom to build, } \\
\text { manage, and } \\
\text { Deploy Software on } \\
\text { massive global network } \\
\text { using the Favorite Tools and } \\
\text { Frameworks }\end{array}$ \\
\hline
\end{tabular}


This presence data collection application uses the App Engine for the web server because the App Engine makes it easy to build, easy to maintain, and easy to scale as traffic and data storage needs develop.

With the App engine the agency pays only what is used. There are no set-up fees and no recurring fees. Consumed application resources such as storage and bandwidth are measured in gigabytes, and billed at competitive rates. The agency can control the maximum amount of application resources used, so it will always stay within the budget. App Engine costs nothing to start all applications can use up to $1 \mathrm{~GB}$ of storage and CPU which is enough to support an efficient application.

B. ODK Collect display

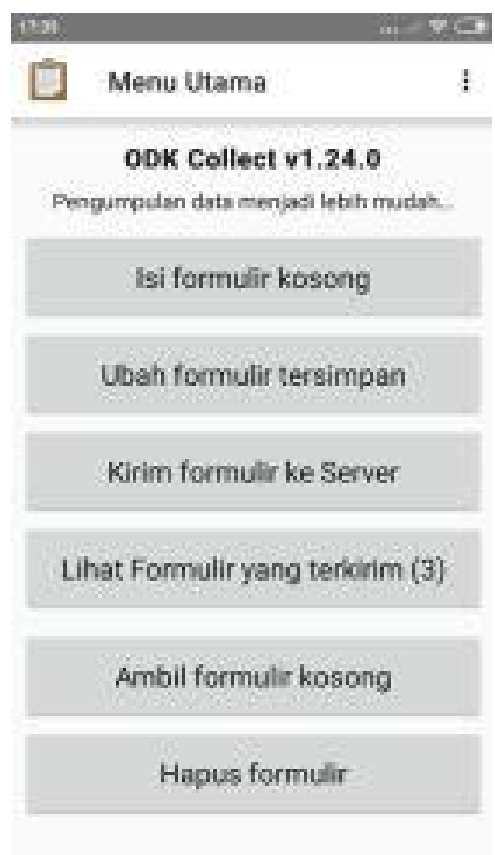

Figure 4 Display ODK Collect

C. Display ODK Aggregate

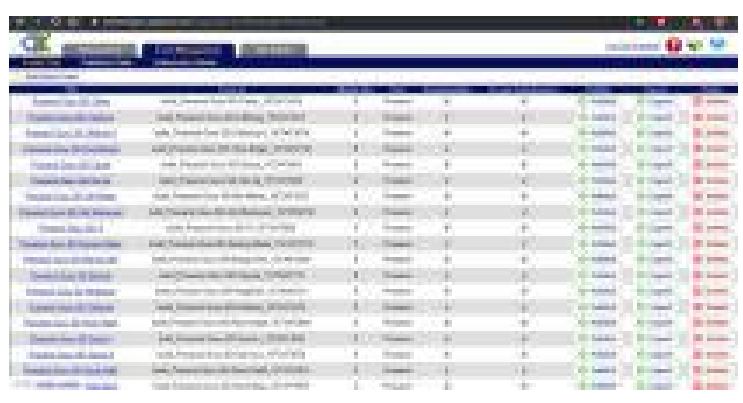

Figure 5 Display ODK Aggregate 


\section{Conclusion}

Ciater District Korwil which refers to the analysis and design that has been made, the following conclusions can be drawn:

1. An Android-based data collection application has been built as a result of the implementation or use of the Open Data Kit (ODK Collect) which can be used by every elementary school teacher in the Ciater District Korwil.

2. Has built a Web application as a server for data management Presence resulting from the implementation or utilization of the Open Data Kit (ODK Aggregate).

3. The data collected by the teacher at ODK Collect can be sent and stored in the ODK Aggregate so that it can be managed by Korwil Operators as needed

4. Data on ODK Aggregate can be exported and downloaded as a CSV file.

\section{Advice}

Based on the stages that have been realized in this research, it is hoped that it can become the basis for further research considering the many limitations faced. Therefore, there are several development proposals, namely:

1. The primary school teacher attendance data collection application is synchronized with the Teacher Performance Application or similar application so that attendance data can be directly connected considering that attendance is one of the teacher performance appraisal invoices.

\section{Recommendations}

With this system, it is hoped that it can help facilitate the collection of attendance data and it is hoped that it can be applied to all institutions or institutions in Ciater District and the system can synchronize with other systems that require attendance data.

\section{References}

[1] S. I, Software Engineering (9th Edition), United State: Pearson, 2010.

[2] Y. Hong, H. K. Worden and G. Borriello, "ODK Tables: Data Organization and Information Services on a Smartphone," vol. NSDR'11, 28 June 2011.

[3] S. Brunette, P. Worden, Anderson and Borriello, "ODK Tables:," Building Easily Customizable Information Applications on Android Devices,, vol. DEV '13, 11-12 January 2013..

[4] Sukarno, "Pengumpulan Data Berbasis Smartphone Android Menggunakan System Open Data Kit," Prosiding Seminar Nasional Pendidikan Teknik Informatika, 2015.

[5] M. Khadafi , T. Away and Nasaruddin, "Penerapan Open Data Kit (ODK) untuk 
meningkatkan Efektifitas Penataan Guru dan Sekolah," Jurnal Online Teknik Elektro Universitas Syiah Kuala, 2017.

[6] Dewi, Anggraeni, Mudjadi and Wicaksono, "Aplikasi Rekapitulasi Elektronik Guru dan Pegawai (AREA-GP) pada sekolah menengah atas," Seminar Nasional Teknologi Informasi dan Komunikasi 2014 (SENTIKA 2014), 2014. 